\title{
Angels Santa, Les avatars du Bossu de Raul Féval en Espagne
}

\section{Erica Tacchino}

\section{(2) OpenEdition \\ 1 Journals}

\section{Edizione digitale}

URL: https://journals.openedition.org/studifrancesi/46154

DOI: 10.4000/studifrancesi.46154

ISSN: 2421-5856

\section{Editore}

Rosenberg \& Sellier

\section{Edizione cartacea}

Data di pubblicazione: 1 octobre 2007

Paginazione: 470

ISSN: 0039-2944

\section{Notizia bibliografica digitale}

Erica Tacchino, «Angels Santa, Les avatars du Bossu de Raul Féval en Espagne», Studi Francesi [Online], 152 (LI | II) | 2007, online dal 30 novembre 2015, consultato il 24 novembre 2021. URL: http:// journals.openedition.org/studifrancesi/46154 ; DOI: https://doi.org/10.4000/studifrancesi.46154

Questo documento è stato generato automaticamente il 24 novembre 2021.

\section{(c) (i) (9)}

Studi Francesi è distribuita con Licenza Creative Commons Attribuzione - Non commerciale - Non opere derivate 4.0 Internazionale. 


\title{
Angels Santa, Les avatars du Bossu de Raul Féval en Espagne
}

\author{
Erica Tacchino
}

NOTIZIA

ANGELS SANTA, Les avatars du Bossu de Raul Féval en Espagne, «Euvres \& Critiques», La réception de la littérature populaire française en Espagne, XXXI, 2, 2006, pp. 75-89.

1 L'articolo offre un quadro dettagliato della ricezione dell'opera di Paul Féval in Spagna, e in particolare del roman feuilleton Le Bossu (1858). Infatti, quest'ultimo ha riscontrato un vasto successo al punto di essere stato molte volte tradotto e riadattato; la studiosa analizza le diverse traduzioni, attua paragoni e dimostra quali siano le differenze sostanziali tra i vari testi. Inoltre, indica i nomi delle principali case editrici, degli illustratori, e dei traduttori che si sono occupati dell'opera di Féval. 